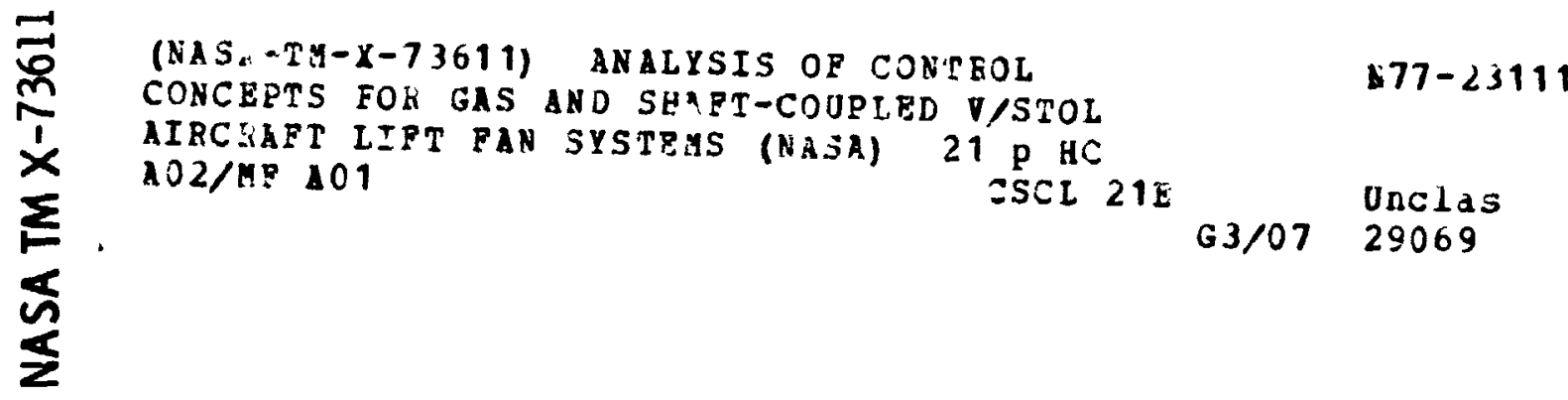

\title{
ANALYSIS OF CONTROL CONCEPTS FOR GAS AND SHAFT-COUPLED VISTOL AIRCRAFT LIFT FAN SYSTEMS
}

h.y James F. Sellers, Clint E.'Hart, and James R. Mihaloew Lewis Research Center Cleveland, Ohio 44135

TECHNICAL PAPER to be presented at the V/STOL Conference sponsored by the American Institute of Aeronautics and Astronautics Palo Alto, California, June 6-8, 1977

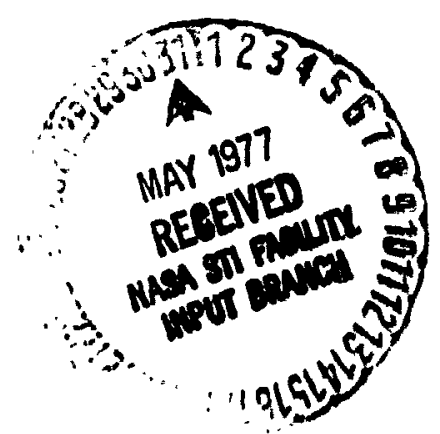


ANALYSIS OF CONTROL CONCEPTS FOR GAS AND SHAFT-COUPLED V/STOL AIRCRAFT LIFT FAN SYSTEMS

\author{
James F. Sellers, C1 int E. Hart, and James R. Mihaloew \\ Nat Ional Aeronautics and Space Administration \\ Jewls Research Center \\ Cleveland, Ohio
}

\section{Abstract}

V/stol aircraft rely on their propulsion systems to provide $11 \mathrm{ft}$ and attitude control moments during hover and low-speed flight. For lift-fan powered V/STOL aircraft, two unconventional propulsion aystem types have been proposed. The first type uses fans connected by hot gas ducting, and the second type uses fans connected by cross shaft1ng. This paper presents results of an analytical study which 1dentifies the basic steady-state and dynamic characteristics for each type of system. For the gas-coupled system, the control concepts analyzed were varlable-area fan turbines and throttling valves in the ducting. For the shaft-coupled systew, the control concepts analyzed were variablepitch fans and varlable fan inlet guide vanes. All of these concepts are shown to be capable of meeting V/STOL aircraft control moment and transient response requirements when appropriate propulsion controls are used. Each type of system has unique problew areas which require an integrated approach to alrcraft/propulsion control design.

\section{Introduction}

V/sTol transport aircraft powered by high bypasa ratio curbofan engines have shown promise for meeting the requirements of civil and military misslons whlch call for long crulse range, large payloada, and Independence from extens lve ground-based alrport facilities. Mision studies have shown that using a minimum number of propulsion units is important in reducing operating cost. To accomplish th1s, the same engines must be used for crulse propulston, lift, and attitude control in hover. The requireat for attitui:e control, in particular, places new demands on the propulsion control systea.

This paper discusese control concepts for two unconventional propulsion system types which have been proposed for the V/STOL application. The first type of systed 1s referred to as a "gascoupled" uyeten and 1s shom in figure 1 . The byetem consists of two or wore ges generators and two or wore 11ft/cruise fans connected by hot gas ducting. In this type of ey:tew, " "gas generator" 1. a Ingle-spool turbojec engin wich supplies hot gas to drive the fan turbint.. The aecond type of ayoten is referred to as a "ahaft-coupled" yeten (t1gure 2) and conelets of two or wore turbofan engines consucted by cross ohefting.

Gas-coupled I1ft-fan eystcas were firet Investiguted In the 1960'. and ceveral different control concepte have been proposed for the (refe 1-7). This etudy is conflaed to two of thee concepts. The firet coacept mploys variablu-ares fan turbinee and the escond enploy throttilns valves in the ducelns ayate. Shaft-coupled turbofane are a recent innovetion, and variuble-rftch fane are the only control concept for the thict-cirupled oyote which the been Invectigated (rate 3,5$)$. This peper andyes both varlable-pltch fave and

STA cetegory 08 variable fan inlet guide vanes.

The objective of this study was to identify the basic steady-state and dynamic characteristics of the gas and shaft-coupled lift fan systems, and to assess thelr ability to meet V/STOL aircraft requirements. To meet the study objective, it was desirable to analyzo the simplest propulsion configurations which still displayed the basic characteristics of each control concept. Therefore, only two-engine systems (figures 1 and 2 ) were analyzed. The two outputs were assumed to be lift (collective thrust) and control moment (thrust difference) about a single alrcraft axis. The control moment could be a pitching or rolling moment depending on afrcraft configuration.

The analysis for each system was performe. using digital computer simulations which predict both dynamic and steady-state behavior of the propulsion systems under study. The analysis is confined to the hovering and low-speed f11ght envelope of V/STOL alrcraft, since this is where the propulsion control requirements are unconventional. The analysis is also conf ined to normal operation. For completeness, failure-compensation aspects of each oystem are discussed qualitatively.

F1gure 3 shows schematically the elemeats of a typical V/STOL atrcraft/propulsion control system. In general, a complete analysis of the V/STOL control problem should Include all of these elements at once, since they interact strongly. However, the scope of this paper 18 confined to the elements inside the dotted ine in figure 3 - the propulsion system and 1ts controls. Such a study is a necessary step toward understanding overall system behavior.

\section{V/STGL Propulsion control Requiremente}

Before discussing propulsion control requirements which are unique to the V/STOL application, It 18 worth noting the mafor requiremente for any propulsion control system. Apart fr regulating the output-thrust-of the engines at the requested leve1, a major function of a propulsion control system is to protect the engines from potentially damaging operating conditions. The most comon protective functions performed by propulation control aystens are the prevention of compreseor or fan surge, rotor overspeeds, and overtemperature of hot-eection componente such as combutors and turbines. An w111 be shown, these 11 itite are usually critical in determining the abllity of a given propuletion eystem to beet V/STOL requirementa.

For V/sTOL alrcraft in hovering and Low-apeed flight, propuletion control requirenente are wore complex than for conventional atreraft. A v/srot. pripuleion control oyatem thould generally be dois gned to meet the following soalle:

\section{Maniales avalleble 11ft (collectiv thruot)}



ence)

2. Maximlze avallable moment (thrust differ-

3. Minimize response time for collective and differential thrust changes

The first goal is desirable since maximum iff implies maximum payload. Maximizing differential thrust capability is also desirable since it implies flexibility to meet the requirements of different alrcraft configurations. Figure 4 shows est imated rol1-axis differential thrust requirements for several aircraft of different gross welght (refs 9-12). For most afrcraft configuratlons, roll-axis control requires more differenthal thrust than pitch-axis control, and therefore imposes the most demanding requirement. The band of typical requirements shown in figure 4 is used throughout this study as a guideline for assessing the moment-producing capability of V/STOL propulsion control concepts.

Minimum response times are also destrable since fast thrust response improves afrcraft handling qualities. Current criteria (ref 13) ind $1-$ cate that differential thrust response should have a time constant less than .20 seconds, and collective thrust response should have a time constant 1 ess than . 30 seconds. "Time constant" $(T)$ is defined as the time required to reach 63 per cent of a commanded step change in collective or differential thrust.

\section{Analysis of Gas-Coupled Lift Fan System}

Figure 1 identifles the essential elements of the gas-coupled 11ft fan system analyzed in this study. The system conststs of two gas generators, two tip-turbine driven lift fans, and hot gas ducting to connect the gas generators and fans. The cross duct permits power transfer between the lift fans and thus enarles the system to develop a thrust difference between the two fans for aircraft attitude control. Total (collective) thrust of the fans is determined by gas generator power output, and differential thrust is determined by the amount of flow tranafer through the cross duct.

Frow the control deslgner's viewpoint, a s1gnif lcant feature of this aystem 1s its four separate rotore, which can and w111 run at four different speds. Ideally, the two gas generator rotors will run at the same speed. The fans, however, must run at different speeds for the system to produce any differential thrust. The control problem, therefore, becomes one of finding the best way of transfering power from one fan to the other to Induce a fan opeed change. The dynamica of fan speed changes w11l tend to doulnate the overall thrust responee time, ince the fans have a high polar mowent of Inertia and change speed at - relatively slow rate.

The gae-coupled ayaten analyzed in this atudy coneleted of two 397 gas senerators and two LF460 lift fans. The J97 is an existing turbojet engina wich ha been eucceufulty run in a ene-coupled eyet configuration (ref 3). The enalytical nodel for the J97 has been verified by comparison wth the experiental reoults of reforence 3. The LF60 10 a 10w-preseure ratio $11 f t / c r u l s e$ fan for which only perforwance predictions are avallbble (ref 14). Table 1 starises the characteriet Ics of the J97/LF460 ayeten for the noninal takeoff condition selected for this study. The results of the analysis are normalized with respect to the values shown in table 1 . Detalls of the analytical model are given in reference 5 .

Varlable-Area Fan Turbiles. - One of the earl1est control concepts proposed for gas-coupled 1 ift fans is the varlable-area turbine concept (ref 1 ). It was selected for analysis in this study because varlable-area turbine technology is presently being developed under the Air Force/Navy Joint Technology Demonstrator Engine (JTDE) program. Present-day turbine technology may render this concept more attractive today than in the mid-1960's when it was first investigated.

A turbine consists of many small nozzles which accelerate the incoming flow before tt impinges on the turbine rotor. The effective flow area of a turbine is roughiy equal to the sum of a11 the individual nozzle areas. The effective flow area can be modulated in two ways, as shown in figure 5 . The first method uses splitter vanes which can be rotated to block some of the individual nozzles. The second method involves rosating all of the stator vanes simultar.eously to produce an area change in each of the individu.i nozzles. In principle, either method could be adapted to a tipturbine lift fan. The first method was demonstrated in reference 1 .

Variable-area turbines can be used to cause flow transfer between gas-coupled $11 \mathrm{t}$ fans. The area of one fan turbine can be increased while the area of the opposite fan turbine is decreased by an equal awount, thus inducing flow transfer from the low-area side of the system to the high-area side. This principle Ingures that the gas generator operating points are not apprectably changed, since the total nozzle area seen by both $g a z$ generators remains roughly constant.

Figure 6 illustrates basic steady-state characteristics of the variable-area turbine concept. Fan thrust and speed, and gas generator exhaust gas temperature (EGT) are plotted againat per cent modulation of fan turbine area. A modulation of 50 per cent means that one fan turbine is set to 150 per cent of its nominal area, while the opposite fan turbine is set to 50 per cent of it a nominal area. Fan thrust and speed are seen to vary linearly with turbine area, whlle gas generator EGT increases by 1 ess than 6 per cent over the full modulation range. Gas generator BGT increases lightly wore on the low-area side than on the higharea 8 ide. Th1s is because excess pressure is required to induce flow through the crose duct, which acts as a preseure losa. The h1gher back pressure on the low-area side gas generator causes it to run at a higher EGT. The limit on differential thrust capability is set by the mount of area variation that can actually be reallzed with practical hardware. The \pm 50 per cent modulation range assumed in this atudy is consistent with the experimental resulte of reference 1 .

P1gure 7 showe a plot of avalleble control noment vereus avallable ilft for the varlable-area turbine sytem. Yor a given elrcraft conflguration, the noulnal 11ft level during hover w11l depend on grose wight, 1.e., the count of fuel or payloed that the alrcraft is carrytne. A V/sToL propuletion syoten nuet be capable of supplying enough differential thrust to wet afrcraft requirementa over a 
normal range of gross weights. Figure 7 also shows a bend of typical differential thrust requirements. Por this study, it was assumed that alrcraft moment of Inert in is proportional to gross welght, a conservative assumption for most configurations. The reduction in moment of inertia at low gross weights causes correaponding reduction in the differential thruat requirement at low gross weights, $1 . e .$, low lift levele. This explains the positive slope of the band of regut rements shown in figure 7 .

Figure 7 Indicates that the variable-area turbine concept can exceed typlcal moment requirements. The positive slope of the moment versus $11 \mathrm{ft}$ characteristic can be explained by the method used to modulate total 1ift. For this study, Iff was modulated by changing gas generator power setting at constant fan turbine area. At low power settings, the total flow avallable to both fan turbines is reduced. Th1s causes a corresponding reduction in the amount of flow which can be transfered to produce differentlal thrust. The moment versus lift characteristic of the variable-area turbine gystem 1s not a problew, since it matches the trend of the requirewents.

As noted earller, the gas-coupled system requires a fan speed increase to generate differentlal thruat. Therefore, the fan must be designed to accowmodate overspeeds relative to the zero-moment condition. The LF460 fan was designed for the $v /$ STOL application and runs below its 1 imiting speed even when generating maximum differentlal thrust. In general, the $1 \mathrm{~lm} 1 \mathrm{ting}$ apeed for a tip-turbine ilft fan should be chosen to match the maximum foreseeable differentlal thrust requirements for different alrcraft configurations.

Throttling Valves. - The varlable-area turbino concept requires complexity in the fan design. To suraount this difficulty, a more recent concept known as Energy Transfer and Control (ETaC) (ref 3) has been developed. As shown in figure 8 , this concept eaploys throttling valves located in the ductIng just upotrean of the fan turbines. By partially closing the valve upstrean of one fan turblne and leaving the opposite valve fully open, flow can be diverted through the cross duct to increase the apeed and thrust of the fan on the unthrottled aide.

Figure 9 show the besic steady-state characterlatice of the throttling-valve concept. As seen In f1sure 9, the thrust characteristic of the throttIling-valve concept is asyonetric. This is due to the Increase in gae generator BGT (about 12 per cent over the avallable throteling range). This partly compenente for the pressure drop acrose the throttling valve and tendo to increase the get power avalleble to the throttled fan. To alntain totel lift conetant while control momente are beling generated, the throttled fan wat be "epolled" to reduce lte thruet level. Spolling can be accompliahed by louvers in the fan exhaust, or by ventIns flov out the elde of the fan exhaut duct.

Homat capability of the throttling-valve concept is linited by the ges senerator BoT 1int. A ces sencrator power setting is reduced, Bor 1o also reduced. The implien that, at low power settinge, wore Ergta is watlable for lacreasing xoT before the linte 1 e reached. Therefore, the throtelingvalve concept can develop wore control monent at 10w powar estinge, l.e., low lift levels. This fact is 1llustrated in figure 10, which shows aval1able control moment versus avallable iff for the throttling-value concept. Although avallable control moment is less at higher lift levels, it is still sufficient to meet most requitements.

Translent Response. - The transtent response characteristics of the throttling-valve concept wlll be presented as typical for a gas-coupled lift fan system. Transient response of the variable-area turbine system is discussed in reference 1 . As mentoned earller, transient response of the gascoupled system tends to be dominated by fan rotor dynanics. To get good moment response from such a system, it is necessary to supply excess gas power to the fan as quickly as possible. Gas power is a function of both flow rate and temperature. The throtting valve controls the amount of flow transfer to the increasing-thrust fan, and gas generator fuel flow determines gas temperature. Therefore, moment response $t$ Ime $c$ an be minimized by applying lead compensation to the throtting valve and by gending an anticipation signal to the gas generator fuel control.

Figure 11 shows a control sygtem designed to take advantage of both effects. A "moment command" signal results in three kinds of action - movement of the throttling valve on one side (with lead compensation to cause an intilal overshoot in valve position); an Increase in fuel flow to both gas generators; and a change in spoller position on the throttled side (with lag compensation to match the response of the spoiled fan to the fan on the opposite side). A "collective thrust command" causes a change in fuel flow to both gas generators as well as a transient reset of spotler position, as will be discussed later.

Flgure 12 shows moment response of the chrottling-valve system with the control aystem of $f i_{g-}$ ure 11. The moment response time constant is .16 geconds, within the range of V/STOL requirements.

For the throttling-valve concept, collective thrust changes are made by changing gas generator power setting. The dynamics of the process are dominated by $f$ an rotor dynamics. However, since spollers are already required for generating moments, they can also be used to quicken the collec.tive thrust response. Th1s can be accomplithed by presetting the spollers to reduce the thrust of the fans by andi amount ( 10 per cent for this study) When a collective thruat increase 1s comanded, this apoiled thruet is made avallable to quicken the response. As fan speed rises to the requested level, the spollers are reset to their or 1 ginal poatcion. This function is labeled "traneient reset" In the controt echenatic of figure 11. Figure 13 show the collective thrust response with a control aystem of this type. The tise constant 1s .09 seconds, well wthin the range of V/STOL requireaents. For the uppor 10 per cent of the avallable 11ft, were chis technique cannot be used, the collect 1ve thrust reeponse has a time constant of .25 seconds (ref 5 ), etill within the required range. At lower iff levels the collective thruat reaponse 1. anginal (ref $S$ ) when the apolling technique is not uced. The apoliling techntque involves a peaalty In tuel conmuption of about 10 per cent. This penulty is coneidered uniaportant ince hovering tine is of ahort duration compared to overall vianion tine. 
The above results show that a gas-coupled systew can meet $V / S T O L$ thrust response requirements when appropriate propulaton controls are used. This conclusion should be considered preliminary until full-scale 11ft fans of the required size are bullt and tested. At present, only estimated values for fan polar moment of Inertia are avallable, and these eat imates might prove optimistic. Furthermore, fan polar moment of Inertia Increases with fan size. Therefore, the above results should be considered typical only for lift fans in the same thrust class $(56,850 \mathrm{~N})$ as the LP460.

Compar 18on of Throtting-Valve and VariableArea Turbine Concepts. - The throtting-valve and variable area turbine concepts both appear capable of meeting $V / S T O L$ requirements with approprlate propuleton control systems. The variable-area turbine concept has the ability to generate control moments at lower temper."'ures than the throttingvalve concept. This is esirable since lower temperature inplies longer engine life. Varlable-area turbines might also provide flexibility for opt 1mizing fuel consumption during mission gegments other than hover (e.8., crulse, lo1ter), but that aspect of their performance was not covered in this study.

The variable-area turbine and thrcttling-valve concepts have noticeably different moment versus I1ft character 1st1cs, as is evident from a comparison of f igures 7 and 10 . Th1s difference $1 \mathrm{~s}$ also due to the fact that the throttling-valve concept produces control moments at higher temperatures than the variable-area turbine concept. At low lift levels, the throttling-valve concept produces large control moments because of correspondingly large tewperature increases. For the varlable-area turbine concept, the reduction in avallable control moment at: low lift levels is not likely to cause probleme since the moment 1s at111 in excess of typIcal requirements.

The relative cost and performance of the two systens is difficult to assess without essuing opecif ic alrcraft configurations and miselon requirements. Innovative dealgns for variable-area turbinea, throttling valves, and thruet spoilera should be sought before a final conclusion is resched, Both syotens are quite complex compared to conventional propuleton syateme, and either one ill require extensive developaent effort on unique componente and overall eyeten Intesration.

\section{Amelyete of Shaft-Coupled Lift Pan Syaten}

Figure 2 bhow the elments of the shaftcoupled lift fan ayoten analyzed in this atudy. The two tan are connected to each other by a crose chaft and gearboxes. The fans can be elther of the verloble-plich type or fixed-pitch type with var1able fan lnlet gulde vanes (IG's), In any laportent respecte, the ayote reseble a tandem-rotor hallcopter.

Deully the fans are run at constant oped. To alutala tha conatant fan apeed, gas generator apad is veried to chnine the total ine powive eupplied to the fan turbines. To eodulate thrust, efther collectively or differentially, wh the fen epend comatant, a neane of changing the fen prenoure ratio 10 required. The fan preseure ratio is a function of blede angle of incidence. Figure 14 illuetrates how fan blade angle of Incidence can be varled by varlable- tch blades or varlable IGV's.

Collective thrust is modulated by collectively changing the pitch angles or IGV settings. Different lal thrust changes are produced by differential$1 y$ changing the pitch angles or IGV sectings of opposed fans. The high-thrust fan absorbs power from the low-thrust fan, with the power transfer occurring through the cross shaft. Total power absorbed by both fans remains roughly constant.

The analytical model for the shaft-coupled system was based on the Qulet Clean Short-Haul ExperImental Engine (QCSEE), a variable-pitch fan engine under development for NASA Lewis Research Center. The QCSEE was chosen for tinis study because of 1 ts similarity to a V/STOL lift/cruise turbofan conf $1 \mathrm{~g}-$ uration, and because the analytical model has been verified by comparison with core engine data and fan model data. Table 1 summarizes the characteristics of the QCSEE for the nominal takeoff cond1tion assumed in this study. Analytical results are normalized with respect to the values shown in Table 1.

Figure 15 shows the steady-state characteristics of the variable-pltch fan concept. Fan thrust and gas generator ECT are plotted against differential pitch setting. The thrust characteristics of the opposed fans are symetric, and control moment is produced at roughly constant gas generator temperature. The steady-state characteristics of the variable-IGV system are $8 \mathrm{Im} 11 \mathrm{ar}$. For the variablepitch and IGV concepts, available control moment is ilmited by the maximum fan blade angle of incidence that can be attalned while st11l malntaining acceptable stall margin. For this gtudy, the var1able-pitch fan was limited to a blade pitch angle 10 degrees greater than the design value. For the IGV concept, the flow turning angle was limited to 10 degree from the axial direction. Both of these IImits apply only to the fan which is increasing in pressure ratio. A decrease in pressure ratio generally increases atall margin.

Figure 16 shows a compariar of avallable control moment versus avallable 1 .t for the variablepitch and varlable-IGV concepta. In this analyals, fan opeed and fan nozzle area were held constant over the moment versus lift range shown in figure 16. The variable-pitch and ICF concepts are seen to produce very simllar performance. The reduction In avallable control woment at high lift levele 18 due to the lint on axaxum blade pitch angle or IGV flow turning angle. The anount of thruat that can be produced on the high-thruet side is fixed regerdlese of totel lift level. Therefore, as total lift increases, the avallable thruat increbent (relative to the cero-ement condition) is reduced.

As shown by f1gure 16, the shaft-coupled eyeten produces leas differential thruat than way be required by one alrcraft configuration. This is a charecteriatic of the particular ensine cycle andlysed in this otudy, and to due to the relitive ise of the sae generator and fan. The Qcsta cas genaretor can eupply enoush power to drive both fane close to the upper linit of blade pitch angle or IGV eating; therefore, a ralatively fall dount of blade pitch or IGV angle la avallable for senerating control soments. This attuntion could be 
altered by asing a sighlly larger fan, which would dbsorb more power at lower blade angles of Inctdence, thus leaving more margin avallable for generating control moments. As is also the case for a gas-coupled system, the optimum tan slze for a shaft-coupled system will depend on the differential thrust requitements of specific aircratt configurations. If a glven fan is intended for use in several different aircraft, it should be sized to meet the largest foreseeable differential thrust requirement.

Transient Response. - Since the fans in the shaft-coupled system can usially be assumed to run at constant speed, the transient response is fundamentally different from the response of a gas-

coupled system. For small chunges in fan thrust, the dynamics are primarily determined by the rate at which fan pitch or IGV setting can be changed. A significant factor in the dynamics of the shaftcoupled system is the corsional resonance of the cross shaft and fans. The cross shaft acts like a torsional spring, and the fans act $11 \mathrm{ke}$ lumped inertias. The result is a 1 ight ly damped spring/ mass type of resonance.

The transient response characteristics of the varlable-pltch and variable-ICV concepts are virtually identical. Therefore, for 1llustrative purposes, only results for the variable-pitch concept w11 be presented.

Figure 17 shows the response of the shaftcoupled system to a step input of differential blade pitch angle. For the transient shown in figure 17, fuel flow to both gas generators was held constant to determine the basic system response without controls. The oscillation in $f$ an thrust is due to the torsional resonance, which causes an oscillation in fan speed. Th1 s type of oscillation is unacceptable in a practical system. Simllar problems occur in shaft-coupled hellcopter propulsion systems ( $r e f$ 15), and the technology for solving them is generally avallable.

The oscillation shown in figure 17 occurs at about 12 Hertz. Electronic filters can be designed which prevent inputs in that frequency range from being applied to the blade pitch actuators, thus preventing excitation of the resonance through the blade pitch Input. Figure 18 shows a control systew with such a filter in the fan pitch actuation system. Also shown 18 a apeed control for the fans. Figure 19 shows the transient response of the shaft-coupled system with the controls of $\mathrm{fig}_{\mathrm{g}}$ ure 18. The torstonal resonance is suppressed, but the response time is noticeably Increased by the presence of the filter. The tive constant is .16 seconds, st11 within the range of $v / 5 T 0 L$ requirements. In this study, a smple second-order 10wpass f1lter was used to prevent excltation of the resonance. A higher-order notch filter wight succeed in improving the response $t$ ime, but in this atudy a conservative approach was used since the imple second-order filter is adequate to meet the requirement. In general, the avoldatice of torelonal resonince ahould be approsched as a problen in aircraft/propuleton control integration, aince the fan pitch controller will be an element Instde an overall alrcraft attitude control loop.

Tigure 20 ahow the collectlve thruat reaponse of the shaft-coupled aystim for a tep input in collective pitch. The control gyated of figure 18 1s applitrable for this type of input. A collective pitch change requires a reset of gas generator speed demand, which is accomplished through the fan speed control. For very large collectlve pitch shanges, gas generator surge and temperature $11 \mathrm{~m} 1 \mathrm{ts}$ could af fret the transient response, but for typlial V/STOL requlrements (roughly \pm 10 per cent lift modulation about a nominal 1. Ift level) this is not a problem. The time constant for the collectlve thrust change is .17 seconds, within the range of V/STOL requirements.

Since the fans in the shaft-coupled system run at constant speed, their polar moment of inertid does not have a primary effect on thrust response. As fan inertia increases, however, the torslonal resonance will tend to occur at lower frequencles. A low-frequency resonance will generally complicate the problem of avolding resonance while still meetIng response requirements. An additional important effect for the shaft-coutled system concerns the number of interconnected fans. Unlike the two-fan system analyzed in this study, a three-fan system will have more than one resonant frequency to be avolded. These problems can be overcome provided they are apprectated at an early stage of development, and provided that an integrated approach is used in the design of an aircraft/propulsion control system.

Comparison of Vardable-Pltch and Variable-IGV Concepts. - The resulics of this study Indicate that variable-pitch and varlable $1 G \mathrm{CV}^{\prime} \mathrm{s}$ give similar performance in a shaft-coupled turbofan system. In generd, variable ICV's of fer less overall range in modulating fan thrust (a variable-pitch fan can produce reverse thrust), but for the V/STOL control application varlable IGV's appear promising. Compared to varlable-pltch, varlable IGV's offer a simplifled actuation system since the moving parts need not be packaged inside a rotating fan hub. A fixed-pitch fan also of fers more design options than a variablepitch fan, since features such as blade mid-span dampers can be Incorporated. In this atudy, the analysis for the variable-IGV concept was based on scaled experimental data and simplifled fan performance prediction methods. Therefore, additional fan aerodynamic design studies and experiments are needed to substantiate the analys is performed in this study.

\section{Compensation for Gas Generator Fallures}

A V/STOL lift fan system must be capable of providing balanced $11 \mathrm{ft}$ after a gas generator fallure. For completeness, the propulsion control aspects of gas generator fallure compensation w111 be discussed qualitatively for both the gas and ahaftcoupled systems.

In a gas-coupled aystem of the type analyzed in this study, two gas generators drive two fans through a comon ducting aystem. Each fan turbine 18 nominally sized to accept the flow from one gas generator. If one gas generator falls, the effective flow area of each fan turbine wust be reduced by half to compensate for the loss of half the ortginal flow. Th1s to not readily accomplished by a fan turbine design wich provides for shutting off half of the avallable turbine admiseton arc. The L\$460, for exmple, has its turbiae inlet acroll separated into two isolated 180-degree adisisalon arca. Half of the acroll can be hut off by cloaing a valve. Therefore, when a gas generator fallure 
occurs, the control system must sense the fallure and close two valves, one for each fan. The falled gas generator must also be 1solated to prevent hot gas from escaping through it in the reverse direction. This 18 done by shutting a third valve (posalbly a passive check valve) fust downstream of the gas generator exhaust. Once the valve is closed, the gas generator cannot be restarted unt 11 after the $a_{2}$ rcraft lands or transit lons to conventional flight.

In sumary, the gas-coupled system requires controls which dre capable of sensing a gas generator fallure and closing the approprlate valves. Analytical results for system performance with a failed gas generator are presented in reference 4. Experimental results are presented in reference 16.

Gas generator fallure compensation for the shaft-coupled system is simpler, and resembles current practice for shaft-coupled hellcopter propulsion systems. Each fan 18 connected to its fan turbine through an overrunning clutch. If a gas generator falls, the fan turbine stops producing power, and the overrunning clutch disengages.

Power 18 transferred through the cross shaf to the fan on the falled side. Since the total power avallable to each fan is cut In half, blade pitch or ICV setting must be collectively reduced. Th1s action can probably be left up to the pllot, as is usually the case with hellcopters. An automatic reset of $f$ an speed and nozzle area might be desirable to maximize thrust at the new fan operating point. If the gas generator fallure 18 temporary (e.8., a compressor stal1), restart can be attempted.

In sumary, the shaft-coupled system does not require automatic controls to successfully compensate for a gas generator fallure, although pllot action to reduce collective blade pitch or IGV angle is required.

\section{Concluelone}

For the gas-coupled $11 \mathrm{ft}$ fan syeten, the anor concluetone of this study are:

1. Aseuning proper fan a1zing, both the variable-area turbine and thrott1ing-valve concepts are capable of producine control momente in excess of typical V/sTOL requirements.

2. As a typical ses-coupled system, the throttling-valve concept appenre capable of aeeting $V /$ STOL thrust reeponse requirements when appropr late propulation controle are used.

3. The varlable-area turbine concept is capable of produclin control comente at lower temperetures than the throttilng-valve concept.

For the shaft-couplad lift fan syates, the a jor concluelone are:

1. Aesuning proper fan e1zing, both the variable-pltch and variable-iGV concepta are capable of producins control ecente in excess of typical v/ sTol requirement.

2. On the beste of ecaled experinatal date and inplified fan aerodynanlc celculatione, ver1ablo-plech fane and variable-IGv's glve otnilar perforence over the thruet nodulation range required for the V/stol application.
3. As a typlcal shaft-coupled system, the vartable-pltch fan concept appears capable of meeting V/STOL thrust response requirements.

4. The shaft-coupled system exhibits a torsion al resonance which must be avolded through careful alrcraft/propulsion control integration.

The above conclus lons are based on an analyt 1cal study and should be considered preliminary unt 11 full-scale hardware expertence 18 galned. It 1s worthwhile to note some of the potential problem areas that were not covered in this study but which should be investigated in the future.

1. Mismatched engines - Usually, any two engines of the same model will show some difference in actual perfurmance as a result of manufacturing tolerances and component deterloration. For both gas and shaft-coupled systems, the performance varlations and control problems result tikg frow such mismatches should be Invest 1gated.

2. Component nonlinearities - Since V/STOL propulsion systems $w 111$ be elements of an overall alrcraft control system, it is essential that fundamental nonlinearities (e.B., hysteresis, deadband) be minimized. Specialized components such as varlable-pltch actuators and throtting valv's must be designed with this problem in mind.

3. P1lot/a1rcraft/propulsion interactions Although propulsion dynamics are an egsential part of overall system dynamics, all the elements shown in figure 3 must be interconnected before integrated system behavior can be explored. To a great extent, this can be accomplished with plloted f11ght simulators incorporating realistic alreraft/propuls Ion analytical models.

4. Rellabilitv/maintainab1lity/coat - Due to the laige number of aensors, actuators, and interconnections required in a V/STOL aircraft/rropulsion control systen, effort must be devoted to developing the components and redundancy architectures needed for a safe, reasonably-priced system.

Although the results of this analytical atudy are encouraglng, wost of the developsent work on $v /$ stol Integrated alrcraft/propulsion controle t111 realns to be done. Before V/stol alrcraft can becoese cout-effective operational syateas, a broad-spectrun controls cechnology ef fort wut be undertaken to drwonatrate solutions to the potential probleas noted above.

\section{Referepces}

1. Suth, E. G., "Investigation of Variable Area Scroll for Power Transfer in Iip Turbine Lift Fan Systens," Rept. 67FP218, 1967, General Electric Co. (USAVLABS-TR-67-26; AD-667989).

2. Taeching, W. A., "MAsA Advanced Llft Fan A1rcrafe Program. Voluen I - LF446 Lift Tan Preliuinary Desion and Installation studies," 1969. General Electrlc Co.

Faschlas. H. A. "MusA Advanced Life Ian A1reraft Progran. Volue II - Conceptunl Desien and Optindestion and Trade-off studies." 1969. General Electric Co.

Fasching, U. A., "MaSA Advanced LIft Fan A1rcraft Progran. Volue III - Technoloty Veriflcation Studies," 1969, General Electric Co. 
Fasching, W. A., "NASA Advanced Lift Fan mircraft Program. Volume IV - LF336 L1ft Fan Programs," 1969, General Electrlc Co.

Anon.: "NASA Advanced Lift Fan Alrcraft Program. Volume $V$ - LF460 Conceptual Design. Trade-off Studies and Technology Verif 1cation Program," 1970, General slectric Co.; also NASA CR-114563.

Anon.: "NASA Advanced LIft Fan Alrcraft Program. Volume VI - LF460 lift Fan Prellminary Design," 1970, General Electric Co.: also NASA Design," 1970.

3. "A Full Scale Test of a New V/STOL. Control System: Energy Transfer Control (ETC)," Rept. MDC-A1588, 1972, McDonnel1 Atreraft Co.

4. Sellers, James F., "Steady State Analysis of Energy Transfer Control (ETC) and Compressor Bleed Concepts of Remote Lift Fan Control," NASA TM X-2876, Sept., 1973.

5. Sellers, J. F., "Translent Analysis of Fnergy Transfer Control (ETC) and Compressor Bleed Concepts of Remote Lift Fan Control," MASA TM X-2863, Sept., 1973,

6. Bayat1, J. E., "The Lift Fan Varlable Area Propulsion Control Concept," NA-75-503. 1975. Rockwell International Corp; also NASA CR137742.

7. Sellers, J. F. and Szuch, J. R., "Control of Turbofan Lift Englnes for V/STOL Alrcraft," ASME Paper 73-CT-20, Washington, D.C., 1973.

B. Zabirsky, J. M. and Burnham, R. M., "Design Conelderations for a V/STOL Technology Airplane," Journal of Aireraft, Vol. 13, Oct. 1976, pp. 745-747.
9. Got1leb, P., Lewis, G. E., and Little, L. J., "Preliminary Design - Lift/Cruise Fan Research and Technology A1rplane F11ght Control Systen," Rept. D180-20216-1, 1975, Boe1ng Aerospace Co.; also NASA CR-137971.

10. "Desizn Definition Study of a Lift/Crulse Fan Technology V/STOL Alrcraft. Volume II: Technology A1rcraft," Rept. MDC-A3440-vo1-2, 1975, MeDonne11 A1rcraft Co.; also NASA CR-13?698.

11. Cavage, R. L., t. al., "Design Definition Study of NASA/Navy Lift/Cruise Fail V/STOL Alrcraft. Volume 1: Sumary Report of Navy Multimlssion Afreraft," 1975, Rockwell International Corp.; also NASA CR-137695.

12. "Conceptual Design Studies of a V/STOL Military. Civil Lift Fan Alrcraft. Addendum to Volumes I and II, Technical Data," MDC-A2707-Vol-III 1974, McDonnell Alrcraft Co.

13. "V/stol Handling Oualitles Criteria. 1: Criteria and D1scussion," Rept. P-577-70, 1970, Advisory Group for Aercapace and Research Development.

14. "LF460 Deta11 Des1gn," Rept. 71AEG297, 1971. General Flectric Co.; also NASA CR-120787.

15. Sw1ck, R. M. and Skarvan, C. A., "Investigation of Coordinated Free Turbine Engine Control Systems for Multiengine Hellcupters," Rept. EDR-5298, 1967, General Motors Corp. (USAAVLBSTR-67-73; AJ-666796).

16. "A Full Scale test of a New V/sTol Control System - Energy Transfer Control (ETC). Phase II - Englne Out Operation," MDC-A1588-Supp11. 1973, MeDonnel1-Douglas Corp.; also KASA $\mathrm{CR}-114596$.

Table 1 Character intics of VTOL lift fan aystean at nominal takeoff condition

\begin{tabular}{|c|c|c|}
\hline & $\begin{array}{l}\text { Gas-Coupled } \\
\text { (J97/LF460) }\end{array}$ & $\begin{array}{l}\text { Shaft-Coupled } \\
\text { (OCSEE) }\end{array}$ \\
\hline Tan Thruat $\left(\mathbf{Y}_{\bullet}\right)$ & $56,850 \times(12,780 \mathrm{1bf})$ & $77,980 \times(17,53016 f)$ \\
\hline Fan spaed $\left(M P_{0}\right)$ & $3967 \mathrm{rpm}$ & 3082 rpa \\
\hline Fan Freasure Dat 10 & 1.29 & 1.27 \\
\hline Fan Airtion & $257 \mathrm{~kg} / \mathrm{eac}(566 \mathrm{1ba} / \mathrm{sec})$ & $396 \mathrm{~kg} / \mathrm{mec}(874 \mathrm{Ibd} / \mathrm{sec})$ \\
\hline Ges Genurator spead & $13,855 \mathrm{rpm}$ & $13,104 \mathrm{rpm}$ \\
\hline Gev Genrator Atrflow & $31.4 \mathrm{~kg} / \mathrm{sec}(69.2 \mathrm{lba} / \mathrm{sec})$ & $31.0 \mathrm{~kg} / \mathrm{sac}$ (68.3 1ta/nec) \\
\hline $\begin{array}{l}\text { Ges Generator Exheust } \\
\text { Gas Tepereture (ECT,) }\end{array}$ & $1019^{\circ} \times\left(1835^{\circ} \times\right)$ & $1182 \cdot x\left(2128^{\circ} n\right)$ \\
\hline
\end{tabular}

(1) sea level atat1e, atandard day

(2) Characterietice show are tor a eingle enalio 


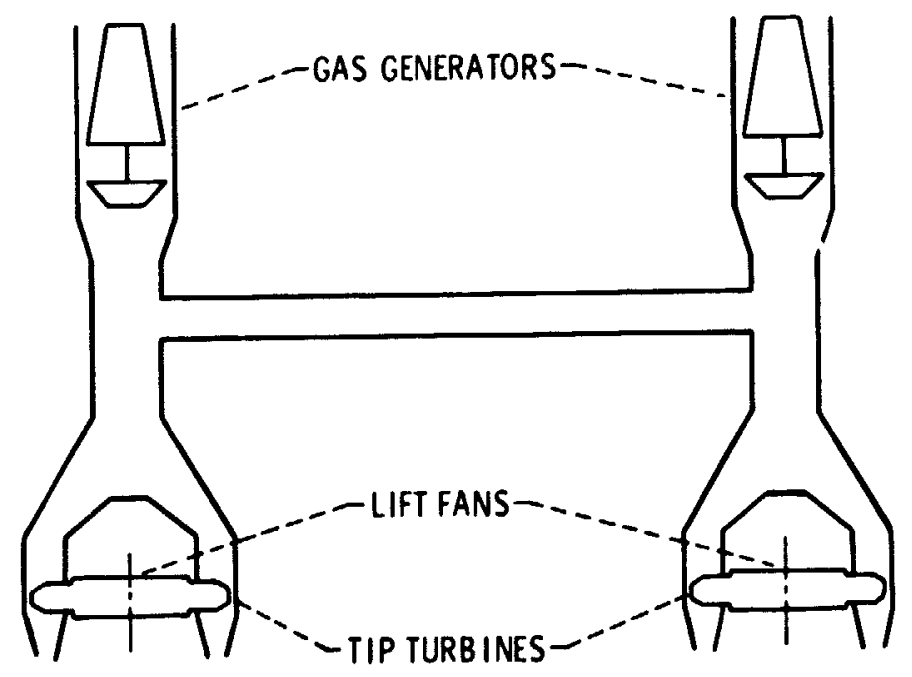

Figure 1. - Gas-coupled lift fan system.

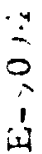

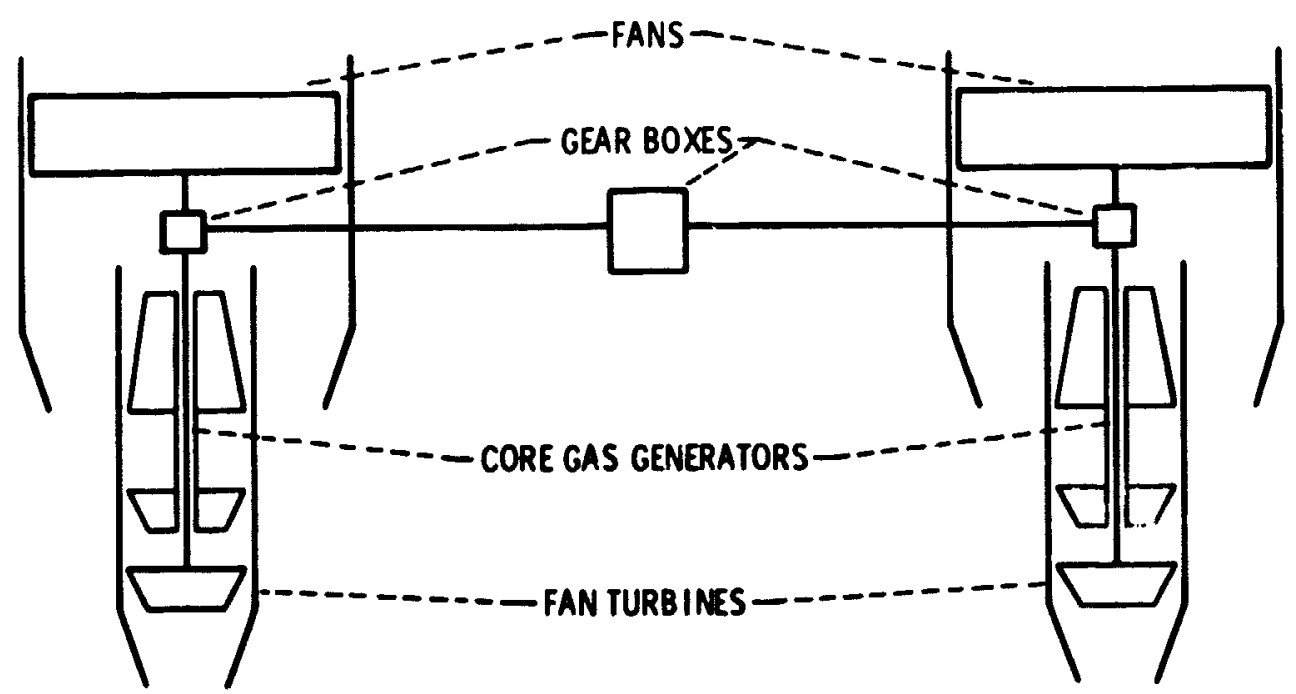

Figure 2 - Shaft-coupled lift fan system. 


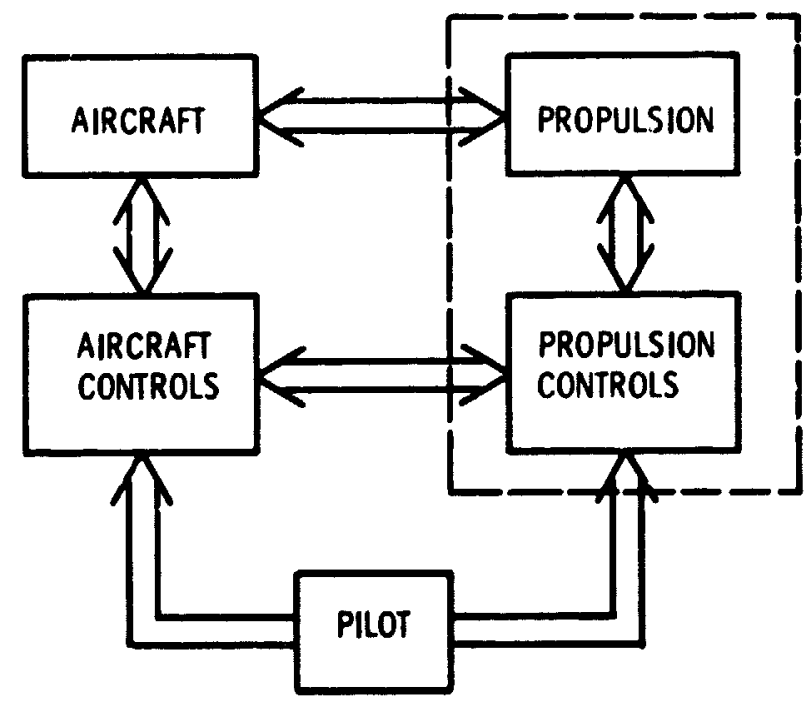

Figure 3. - Elements of a V/STOL aircraft/propulsion control system.

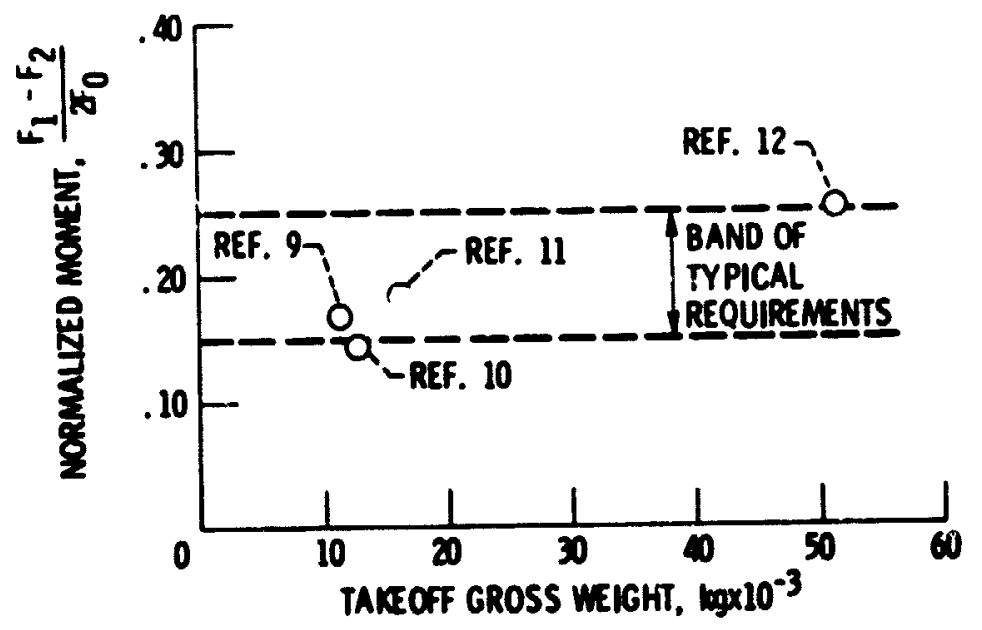

Figure 4. - viO aireratt differential thrust requirements for roll control. 

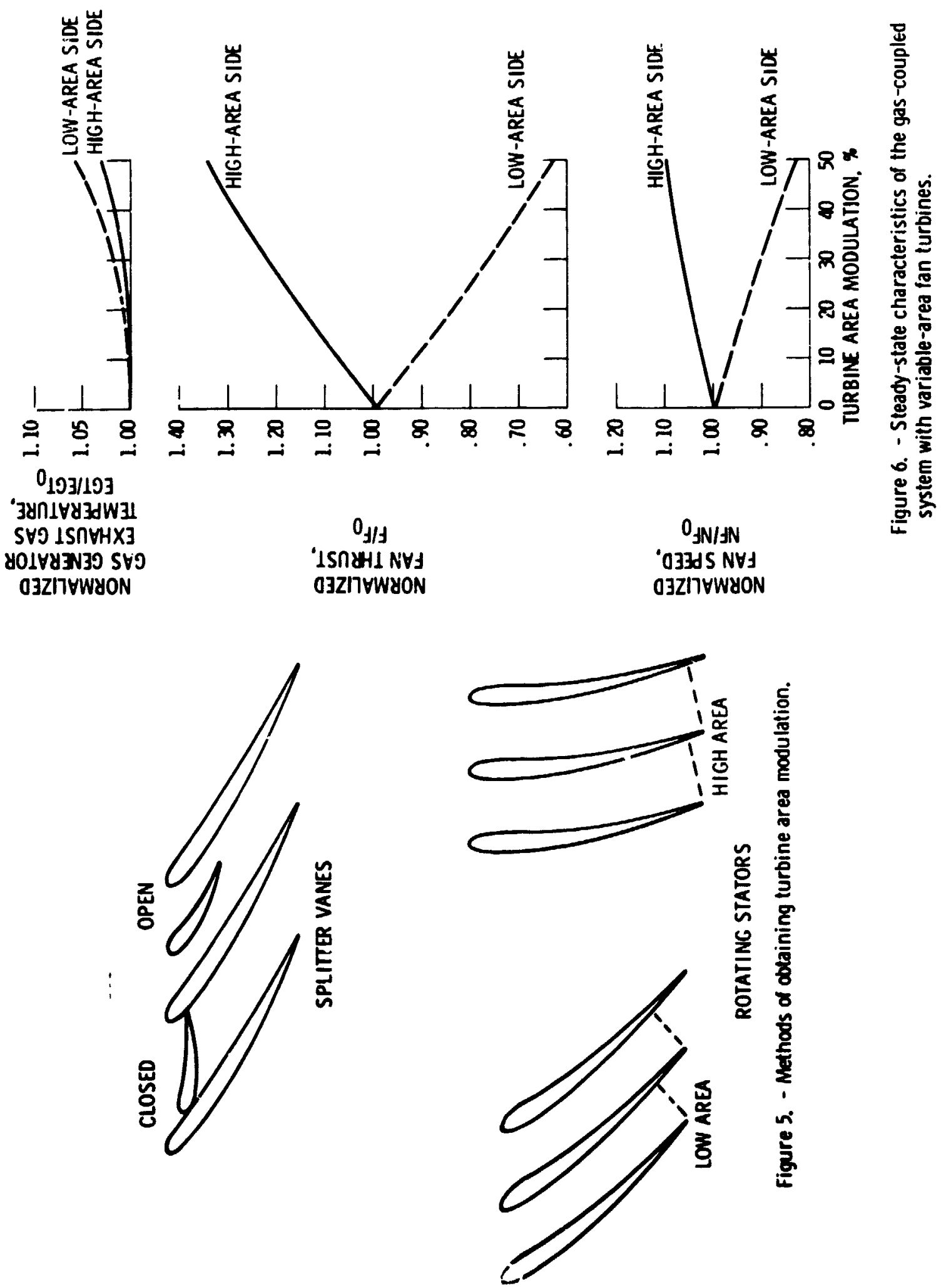

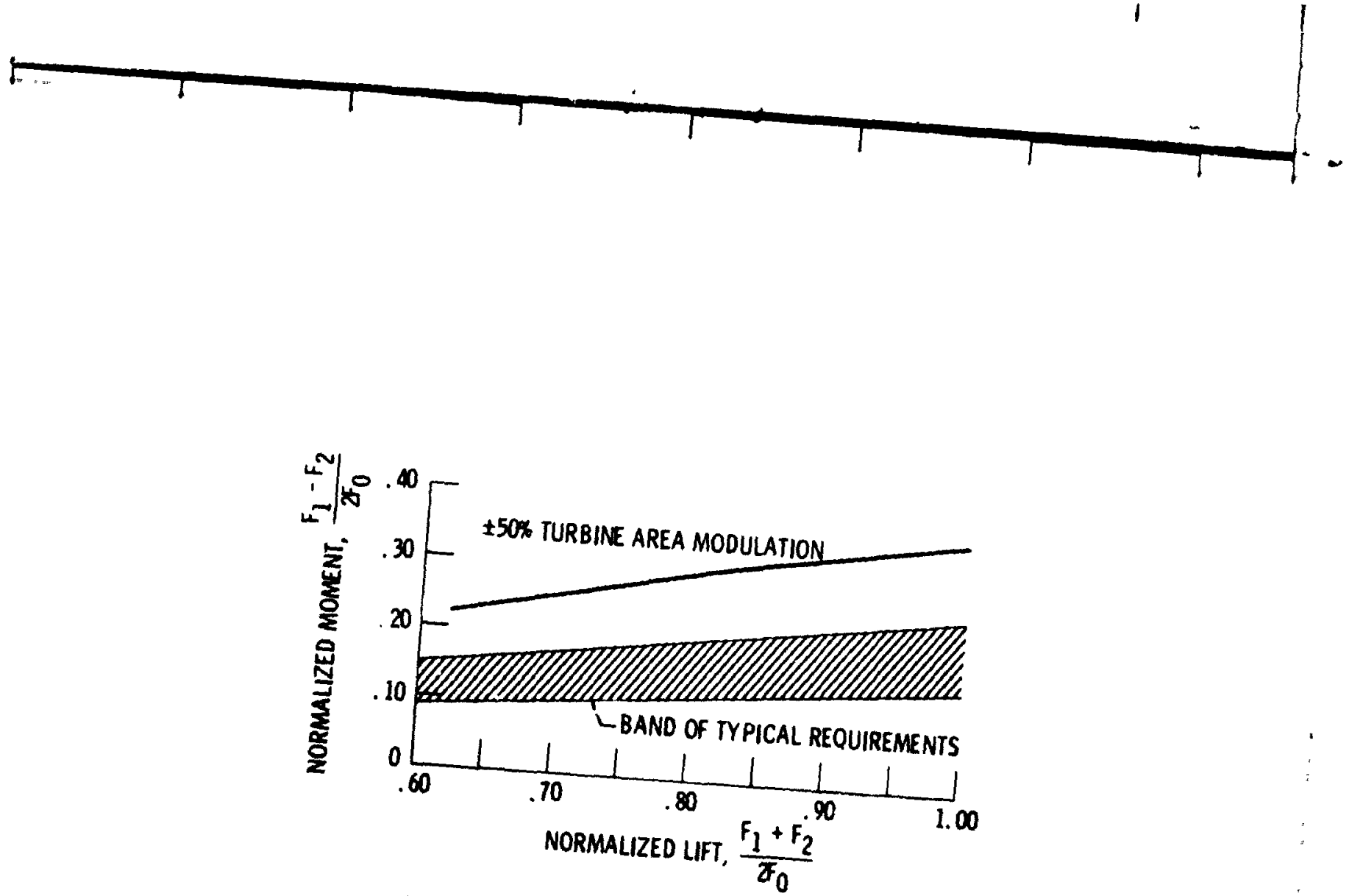

Figure 7. - Available control moment versus available turbines.

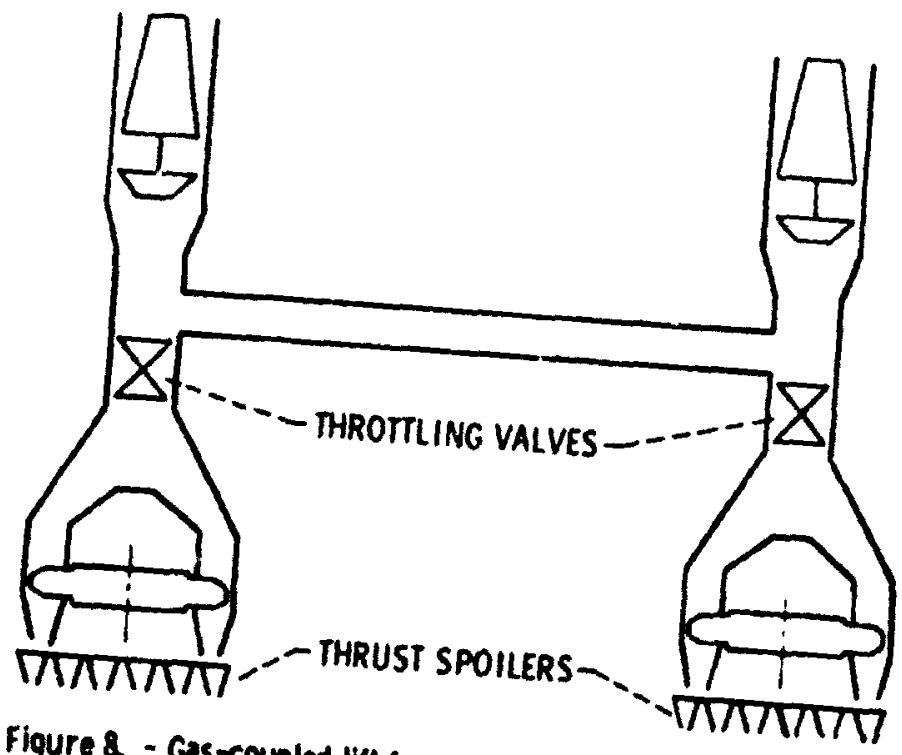

Figure \& - Gos-coupled lift fans with throttling valves for flow
transfer.

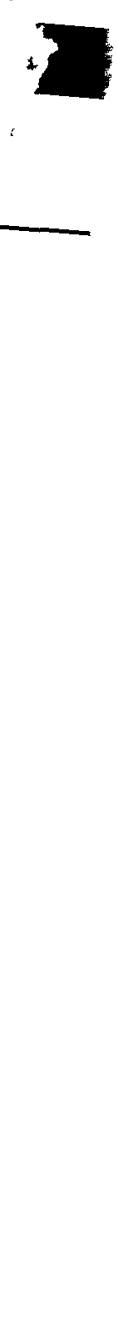



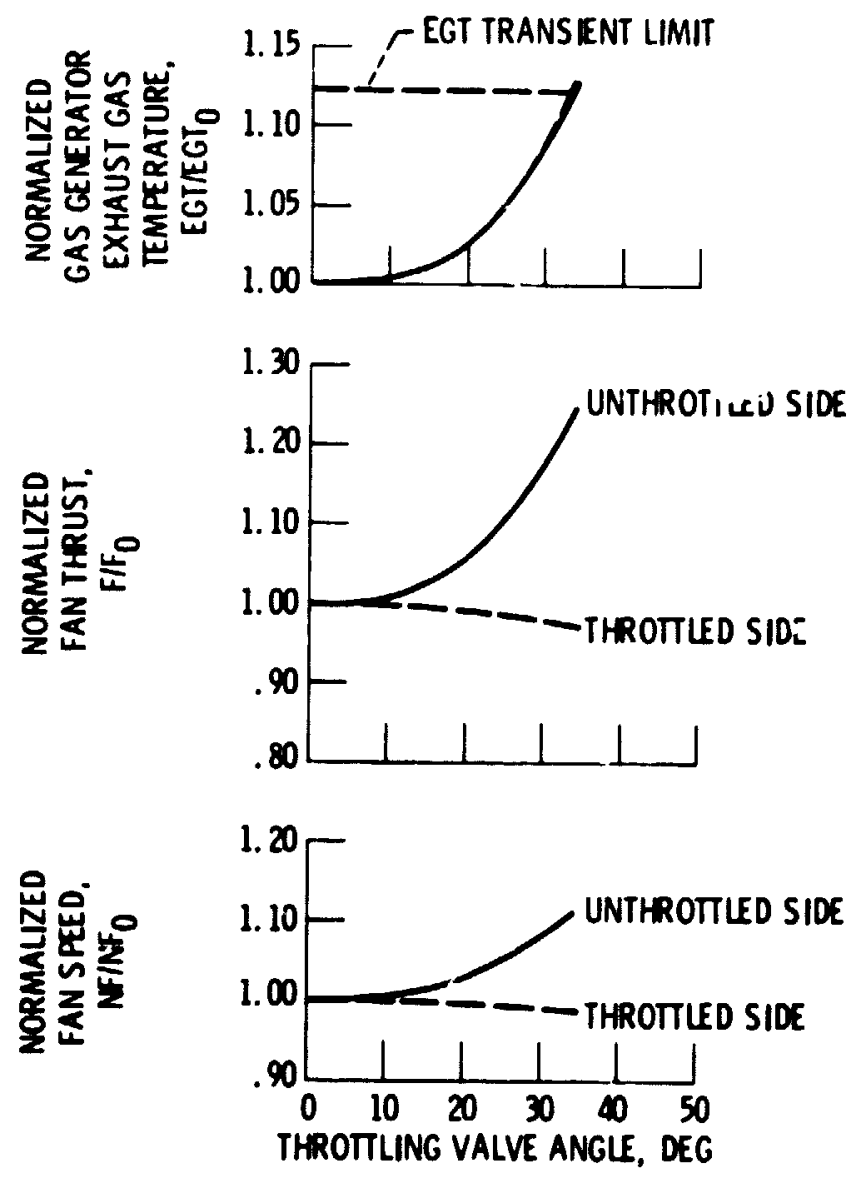

Figure 9. - Steady-state characteristics of the gas-coupled system with throttling valves.

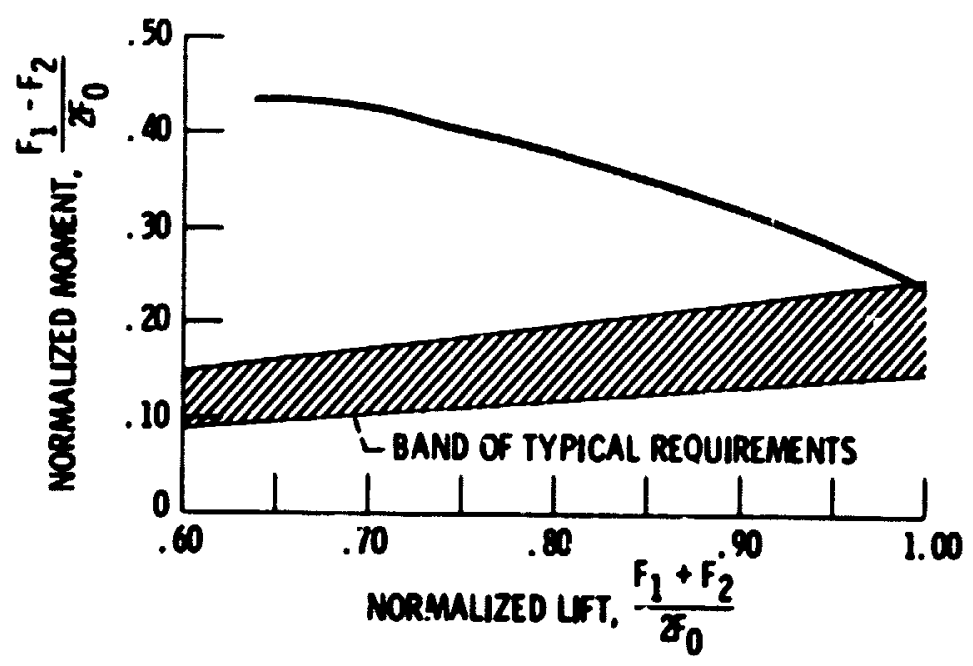

Flgure 10. - Avalioble control moment wersus arolloble Iift lor the gas coupled system with thretting values. 


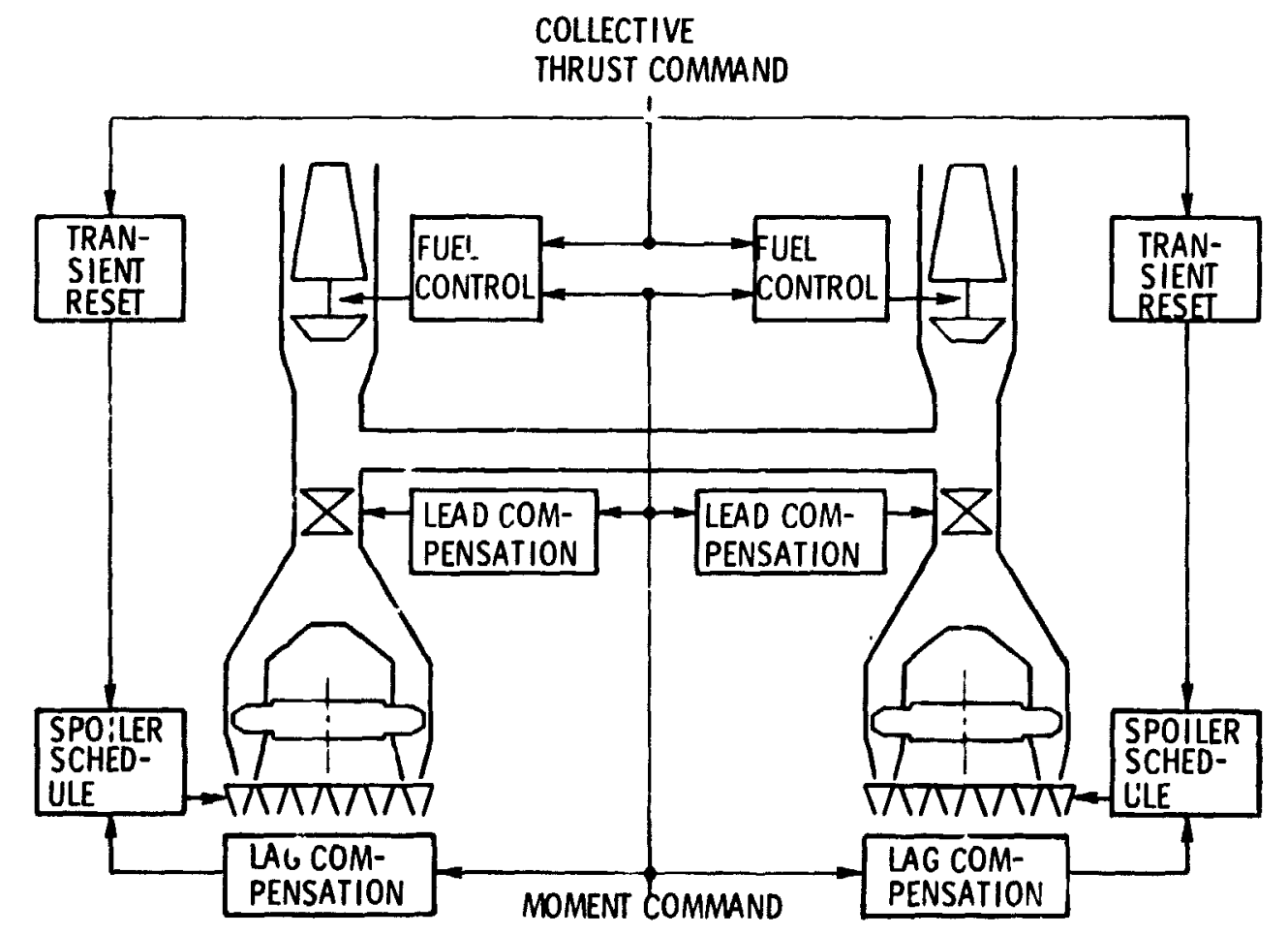

Figure 1l. - Control system for gas-coupled lift fans with throttling valves. 

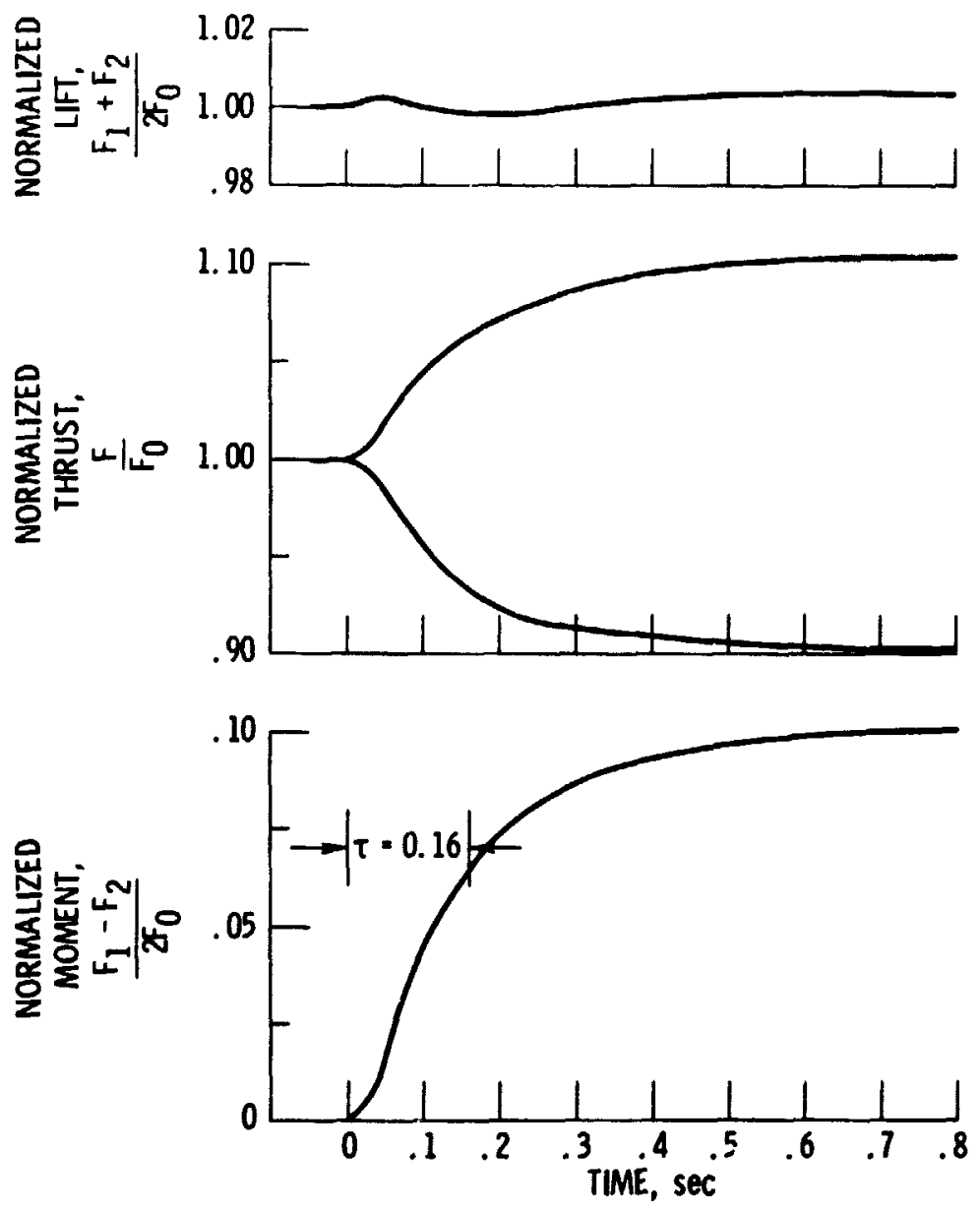

Figure 12. - Response of gas-coupled system with throttling valves to a step in moment request.

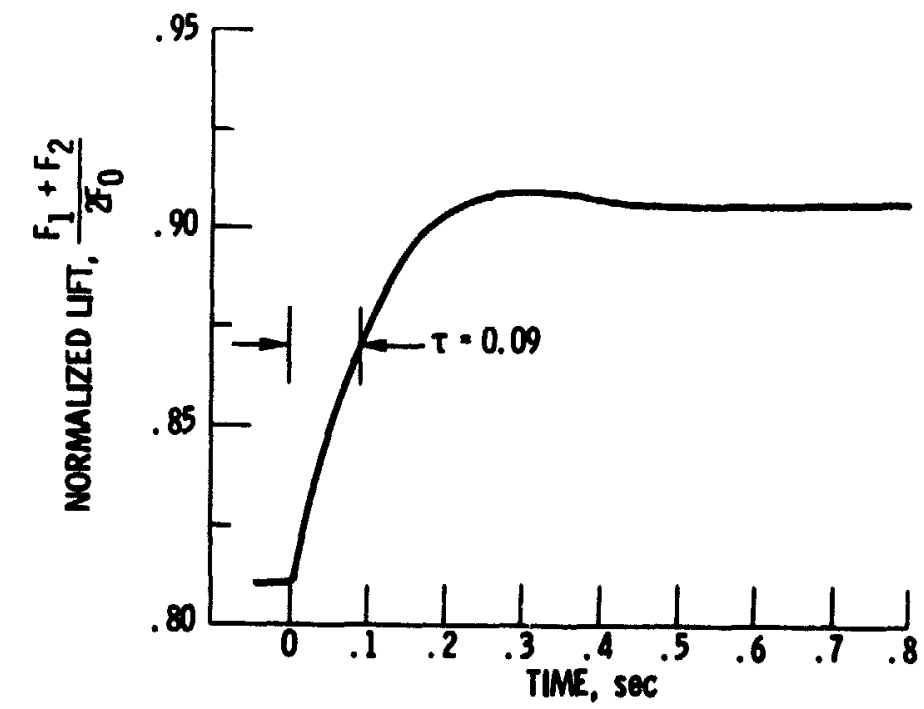

Figure 13. - Response of gas-coupled system to a step in collective thrust request. (Spoilers used to improve response.) 

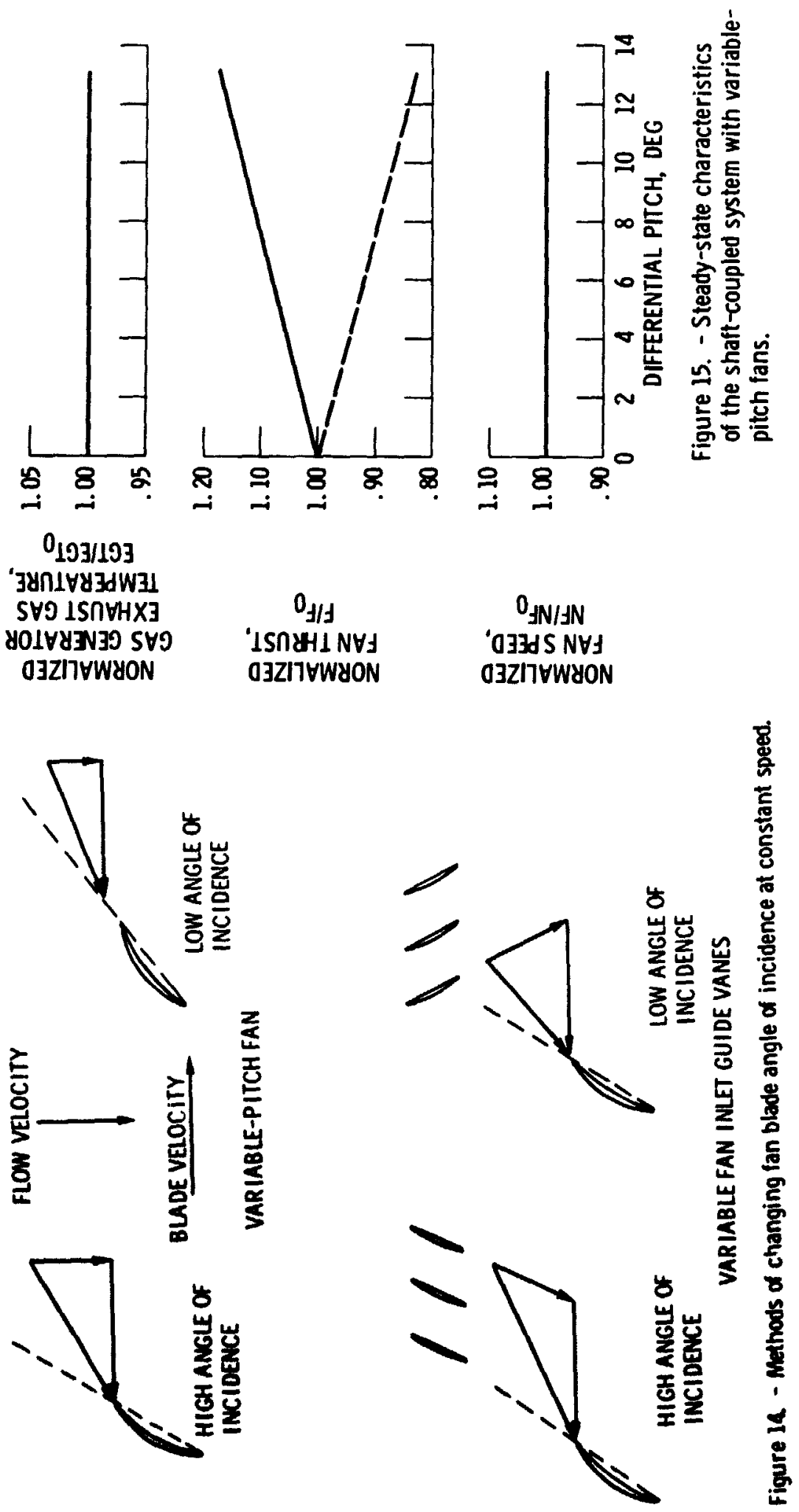


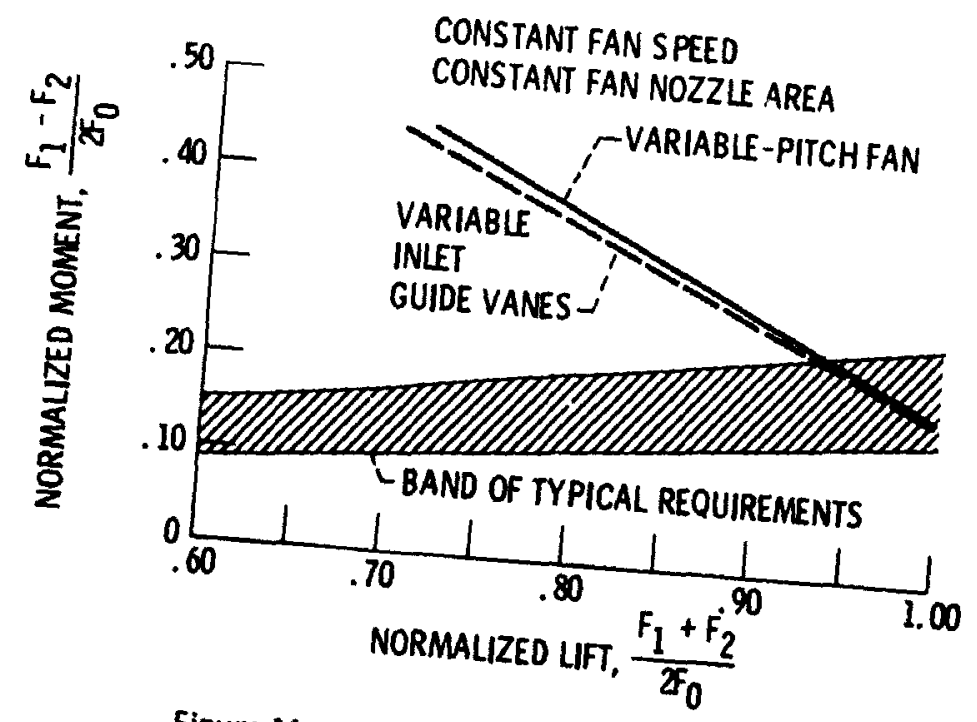
Figure 16. - Available control moment versus available
lift for shaft-coupled lift fans. 

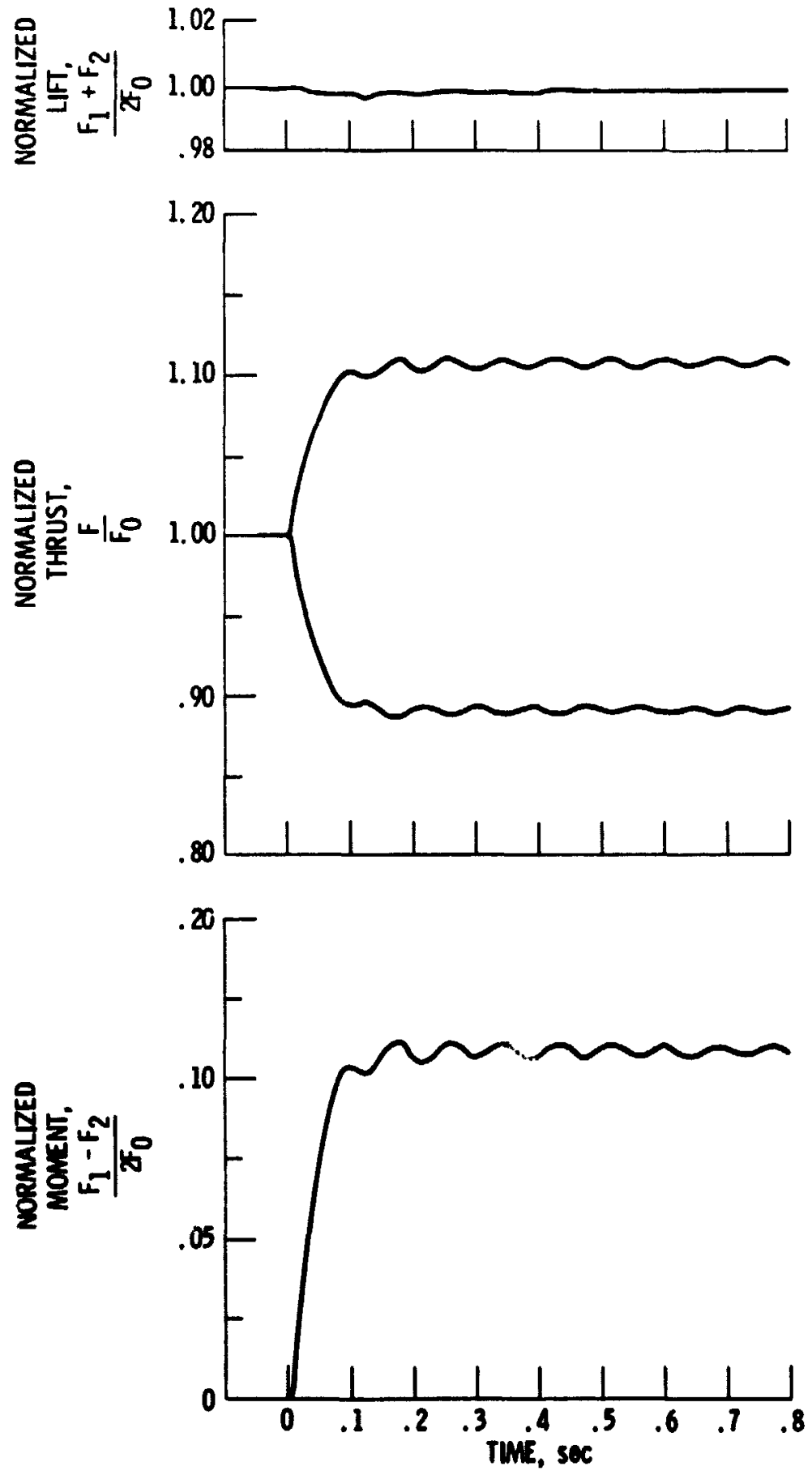

Figure 17. - Response of shaft-coupled system to a step in difforential plich (no controls). 


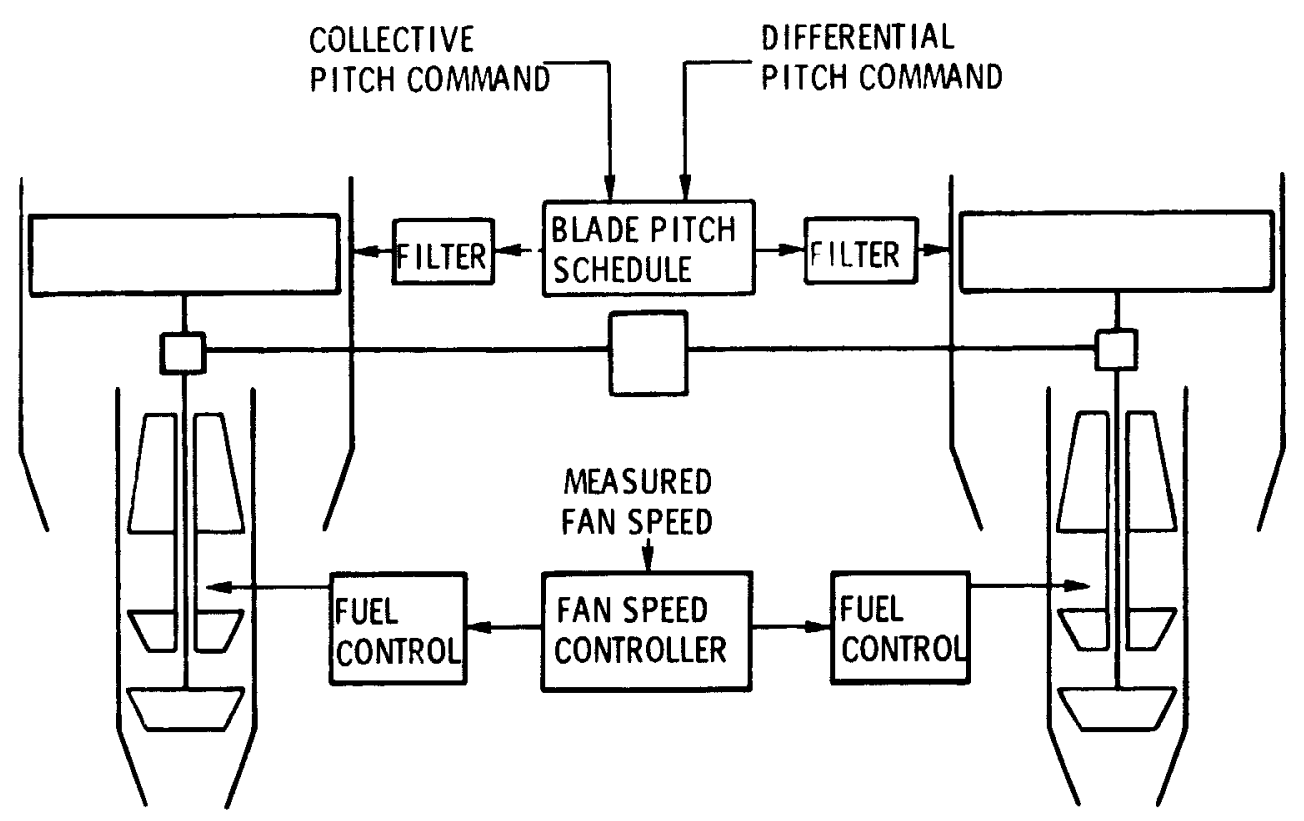

Figure 18. - Controls for shaft-coupled system. 


\section{$F$}
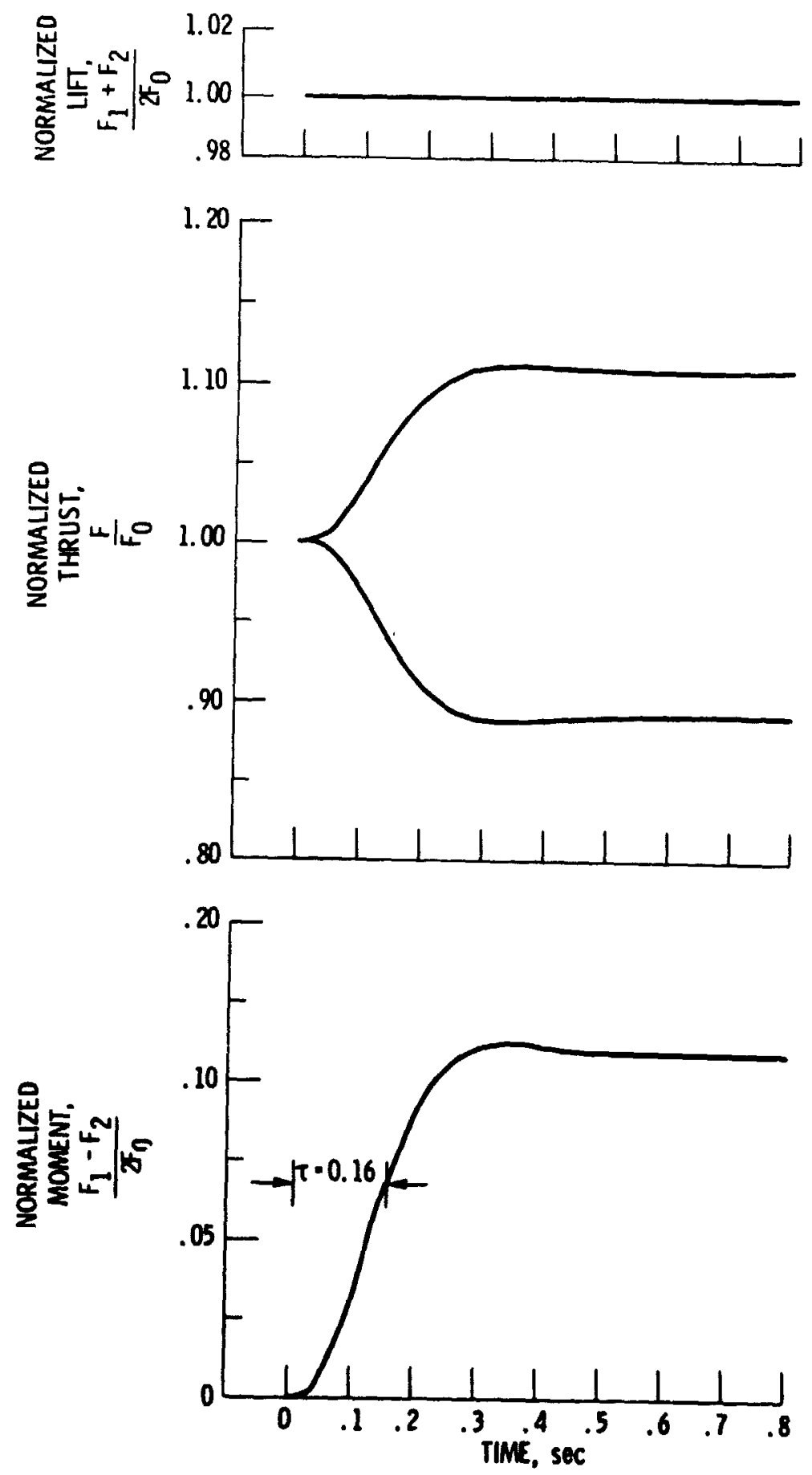

Figure 19. - Response of shaft-coupled system to a step in differential pitch request ifiltered inpu":. 


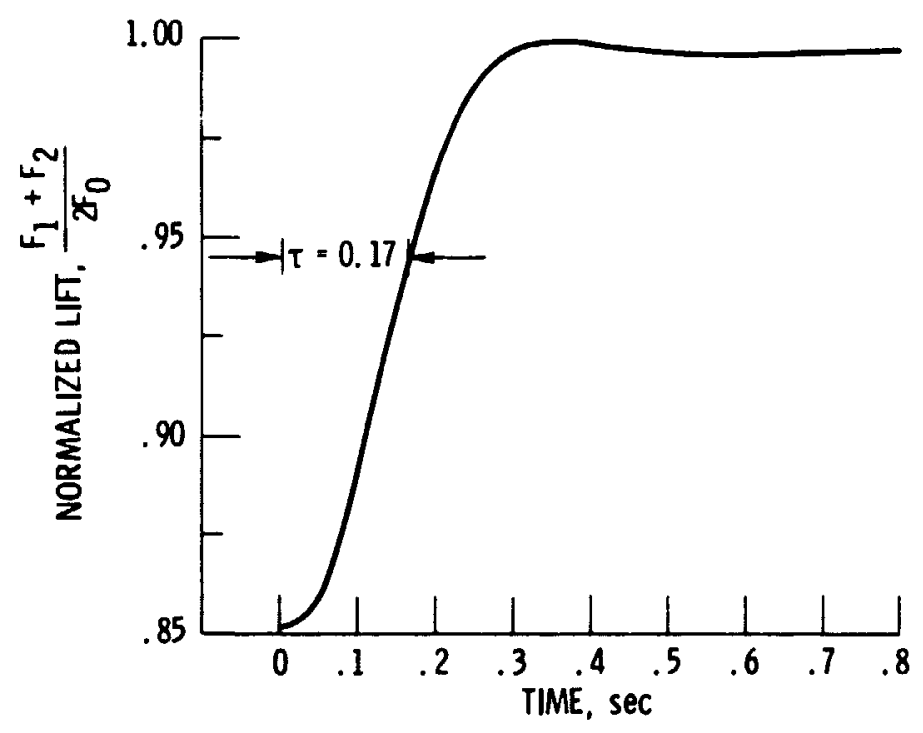

Figure 20. - Response of shaft-coupled system to a step in collective pitch request (filtered input). 